\title{
New Determinants in Mandibular Regeneration Induced by Immediate Load Dental Implant
}

\author{
Maurizio Catinari $^{1}$, Manuel Scimeca ${ }^{2 *}$, Massimo Amorosino ${ }^{1}$, Mario Marini ${ }^{3}$, Elena \\ Bonanno $^{4}$, Virginia Tancredi ${ }^{3}$
}

${ }^{1}$ Studio Dentistico Catinari, ViaSaponara 107, 00125 Rome

${ }^{2}$ Department of Biomedicine and Prevenction, University of Rome Tor Vergata, Via Montpellier 1, Rome 00133, Italy

${ }^{3}$ Department of Systems' Medicine, University of Rome Tor Vergata, Via Montpellier 1, Rome 00133, Italy

${ }^{4}$ Department of Experimental Medicine and Surgery, University of Rome Tor Vergata, Via Montpellier 1, Rome 00133, Italy

*Corresponding author: Manuel Scimeca, Department of Biomedicine and Prevenction, University of Rome Tor Vergata, Via Montpellier 1, Rome 00133, Italy, Tel: + 390620903913; E-mail: manuel.scimeca@uniroma2.it

Citation: Scimeca, M., et al. New Determinants in Mandibular Regeneration Induced by Immediate Load Dental Implant. (2018) Lett Health Biol Sci 3(1): 5- 6.

Received date: March 27, 2018

Accepted date: May 02, 2018

Published date: May 07, 2018

\section{Short communication}

Periodontitis is an inflammatory disease of the supporting tissues of the tooth, caused by gram negative bacteria, resulting in progressive destruction of the bone supporting tissues of the tooth ${ }^{[1]}$. It is usually accepted that periodontitis is started by complex microbial biofilms which form on the teeth, i.e. dental plaque. Substances released from this biofilm such as lipopolysaccharides, antigens and other virulence factors, gain access to the gingival tissue and initiate an inflammatory and immune response, leading to the activation of host defense cells. As a result of cellular activation, inflammatory mediators, including cytokines, chemokines, arachidonic acid metabolites and proteolytic enzymes collectively contribute to tissue destruction and bone resorption $^{[2]}$.

In our recent study, we demonstrated that the bone load applied by titanium implant was able to induce the mandibular osteogenic reconstruction by studying the composition of mandibular cellular population before and after surgery ${ }^{[3]}$. The scanning electron microscopy and EDX analysis ${ }^{[4]}$ of new formed bone showed the absence of inflammatory cells, no/rare osteoclasts and numerous cluster of osteoblasts. Thus, we can speculate that the application of immediate load dental implant influence bone metabolism inducing the recruitment and differentiation of osteoblasts ${ }^{[3]}$.

Now, we expanded our study investigating the molecular factors that support mandibular regeneration after immediate load dental implant. In particular, we examined the expression of bone morphogenetics proteins 2 (BMP-2) and sclerostin in mandibular bone biopsies. To this end, we investigate 10 small mandibular fragments of patients affected by periodontitis with no contraindications for dental implants, underwent open sur- gery for the application of endosseous titanium implants (BANP IMPLANT S.R.L., Milan, MI, Italy) with immediate load dental implant technique. Biopsies were taken at the time of surgery and at the visit control (6 months). Histological, immunohistochemical and ultrastructural analysis allow us to demonstrate that mandibular regeneration that we observed in all patients could be related by the increase of the expression of BMP-2. Indeed, we observed rare BMP-2 positive cell in mandibular biopsies take at the time of surgery, whereas after 6 months we noted a significant increase in BMP-2 expression. It is important to note, that BMP-2 is considered the most important osteo-inductive factor, able to induce osteoblasts recruitment and differentiation. Concomitantly with the increase of BMP-2 expression we also observed the absence of sclerostin in biopsies taken at the visit control (during mandibular regeneration). Sclerostin is a small protein expressed by the osteocytesin response to mechanical load applied to the skeleton and appear to play an important role in the regulation of bone remodeling. Specifically, in absence of load osteocytes increase the expression of sclerostin blocking the osteoblasts differentiation.

In conclusion, all together our results reported support the idea that, at molecular level, immediate load dental implant can induce mandibular regeneration by both inducing BMP-2 and reducing sclerostin expression. These evidences can lay the foundation for development of drugs able to prevent/cure the mandibular resorption associated to periodontitis. Indeed, are already available biological drugs concerning these molecules, human monoclonal anti-sclerostin antibodies and human recombinant BMP-2.

Acknowledgments: Authors wish to thank Dr. Alessandro Polidoro for technical support.

Copy Rights: (C) 2018 Scimeca, M. This is an Open access article distributed under the terms of Creative Commons Attribution 4.0 International License. 
Citation: Scimeca, M., et al. New Determinants in Mandibular Regeneration Induced by Immediate Load Dental Implant. (2018) Lett Health Biol Sci 3(1): 5- 6.

Conflict of Interest Statement: There are no potential conflicts of interest relating to the manuscript (for each authors), and there were no extramural sources supporting this research (excluding sources already declared). The study is original and the manuscript has not been published yet and is not being considered for publication elsewhere in any language either integrally or partially except as an abstract. All authors have agreed with the submission in its present (and subsequent) forms.

\section{Reference}

1. Bosshardt, D. D. The periodontal pocket: pathogenesis, histopathology and consequences. (2018) Periodontol 2000 76(1): 43-50.

Pubmed | Crossref | Others

2. Yucel-Lindberg, T., Båge, T. Inflammatory mediators in the pathogenesis of periodontitis. (2013) Expert Rev Mol Med 15: e7.

Pubmed | Crossref | Others

3. Scimeca, M., Bischetti, S., Bonanno, E. Energy Dispersive X-ray (EDX) Microanalysis in Biomedical Research. (2016) Lett Health Biol Scil (1): 10- 11.

Pubmed | Crossref $\mid$ Others

4. Catinari, M., Scimeca, M., Amorosino, M.,et al. Mandibularregenerationafter immediate loaddentalimplant in a periodontitispatient: A clinical and ultrastructural case report. (2017) Medicine (Baltimore) 96(15): e6600.

Pubmed | Crossref | Others
Submit your manuscript to Ommega Publishers and we will help you at every step:

- We accept pre-submission inquiries

- Our selector tool helps you to find the most relevant journal

- We provide round the clock customer support

- Convenient online submission

- Thorough peer review

- Inclusion in all major indexing services

- Maximum visibility for your research

Submit your manuscript at

https://www.ommegaonline.org/submit-manuscript 